\title{
Identifying Groups of Entrepreneurial Activities at Universities
}

\author{
Daniel Fuller Soochow University, Suzhou, China
}

David Pickernell University of Portsmouth

\begin{abstract}
Purpose - To identify whether the entrepreneurial activities of Universities in the UK can be statistically grouped together.

Methodology - Performing a Principle Component Analysis (PCA) of the 2009/10 UK Higher Education Business and Community Interaction Survey (HE-BCIS) data for the third stream activities of Universities in the UK. This paper aims to identify whether the entrepreneurial activities of Universities in the UK can be statistically grouped together.

Findings - The PCA of the 144 included institutions identified 4 groups of entrepreneurial activities being engaged in by Universities in the UK. 3 of the 4 groups were related to spin-offs, labelled as "Staff Spin-off Activity", "Non-HEI Owned Spin-Off Activity" and "Graduate Start-up Activity". The remaining factor has been named "University Knowledge Exploitation Activity (UKEA)" and encompasses a wide range of university knowledge creation, exchange and exploitation activities.

Research Limitations and Implications - The research indicates, through a ranking system for each university for the various groups of entrepreneurial activities, that Universities are often entrepreneurial in just 1 or 2 of the groups of entrepreneurial activities identified by the PCA. Identifying what is causing those differences is required to further understand why we see this variation across the $\mathrm{HE}$ sector.

Originality - The use of a PCA to identify groups of entrepreneurial activities is a novel approach. Typically studies use a select few indicators, such as spin-offs or patents to analyse the entrepreneurial activities of Universities. This study uses PCA to group together statistically related activities which can then be used to identify what is driving these groups of activities in future studies.
\end{abstract}

Keywords Entrepreneurial university, Principal Component Analysis, Spin-Offs, Knowledge Exploitation, Rankings

Paper Type Research Paper 


\section{Introduction}

Since the Lambert review (Lambert 2003) there have been a number of government sponsored reviews of the role that universities are playing in the wider economy. The Warry report (2006), the Sainsbury review (2007) and the Wilson report (2012), have all considered the changing economic role of universities, this potential paradigm shift in the role of universities (Etzkowitz et al., 2000) an issue of ongoing government policy debate (e.g. see; Culkin, 2016;Reddy, 2011; Bercovitz and Feldman, 2006), also illustrated in the UK by the increasing role of "impact" in the Research Exercise Framework (Smith et al., 2011).

This has led to a greater focus on the Third Stream Activities (TSA) of universities generally (Hatakenaka, 2005; Molas-Gallart et al., 2002), but also increasing interest in the concepts of the entrepreneurial university specifically (Etzkowitz, 2003). This discussion has hitherto mainly focused on the innovationrelated activities of the university itself, but can also include the more widely defined enterprising university (Woollard et al., 2007), which can include other activities such as enterprise education and graduate entrepreneurship (Pruett et al., 2009; Jack and Anderson, 1999; Hannon et al., 2005; Matlay, 2006; McLarty, 2003;)).

Previous studies have shown that different types of university, or faculties are more adept at different types of entrepreneurial activities (Abreu et al., 2009; Caldera and Debande, 2010; Hewitt-Dundas, 2012). This also overlaps with other university definitional discussions. Hewitt-Dundas (2012) showed, for example, that LRI (Low Research Intensive) universities which are typically post-92, were more focused upon engaging with regional players than $\mathrm{HRI}$ (High Research Intensive) universities, who were often able to attract national and international partners due to their higher research standing.

Previous studies of university TSA have, however, focussed on a specific channel of university's commercial activity, or a select few channels. The typical approach to investigating the commercial activities of universities is to analyse individual activities such as; patenting (Acosta et al., 2012; Di Gregorio and Shane, 2003; Perkmann et al., 2011), licensing (Powers and McDougall, 2005; Siegel et al., 2003; Siegel et al., 2008), creation of spin-offs (Avnimelech and Feldman, 2011; D'Este and Perkmann, 2011; O'Shea et al., 2005), other forms of engagement (Perkmann et al., 2011; Van Looy et al., 2011), or a mixture of these activities (Caldera and Debande, 2010).

This restricts the usefulness of the findings when looking at the role of the university sector as a whole, specifically the lack of studies that include the potentially important role of graduate entrepreneurship amongst the variables studied. This is important because Åstebro et al., (2012) found that graduate entrepreneurship (through start-up creation) was of an order of magnitude higher than the number of staff creating start-ups.

More broadly, because of the disparate nature of university's TSA activities, this study aims to identify sets of entrepreneurial activities undertaken by universities, , allowing rankings of universities using those sets of activities, to better inform government policy in this area.

Our paper also aims to take a different methodological approach to those used previously. Whilst the above papers have used a select number of variables to be studied, whether that be patenting, licensing, spin-offs, or all three, the choice of variable studied was always determined by the academics in question.

In this study, however, Principle Component Analysis (PCA) is used to statistically identify groups of variables that are statistically similar within their 
groups. This approach allows university activities to be identified within distinct groups, allowing better understanding of how universities are engaging in commercial activities in certain areas.

The rest of the paper is structured as follows. The next section explores the literature related to the entrepreneurial activities undertaken by universities in order to identify the variables of potential relevance to the study. This is followed by outlining the methods and data set used. The results obtained are then reviewed, followed by a discussion of the rankings for each of the factors identified. Finally, the conclusions section identifies the policy relevance of these results as well as future research potential.

\section{Entrepreneurial Activities Undertaken by Universities}

Higher Education Institutions (HEIs) have increasingly been encouraged to take a larger role in economic development (e.g. see Lazzeretti and Tavoletti, 2005; Lenger, 2008) particularly through innovation (Benneworth, 2007). Increased government policy efforts have therefore been focused in many countries to more directly commercialise the outputs of university research in some way.

The previous role of Universities as centres for teaching and research has therefore been supplemented by the need to increase the economic performance of the economies in which they sit (Etzkowitz and Leydesdorff, 1999; Gibb et al., 2009). Reductions in spending on higher education and increasing student numbers also mean that Universities have been forced to develop third stream (external) sources of income (Gibb et al., 2009; PACEC, 2009).

This also changes the traditional view of a university's purpose and values, which focuses on knowledge for its own sake; making knowledge freely available to all (Behrens and Gray, 2001); organised scepticism (Kenny, 1987); and learning. The new more entrepreneurial paradigm for universities instead involves a greater focus on direct economic value creation and exploitation for the university than previously (Behrens and Gray, 2001; Harman, 2006), potentially creating tensions between teaching and theoretical research activities related to a university's traditional academic reputation and its more recent direct economic development role (Jarzabkowski, 2005).

The activities analysed within this study can be seen to fit within 'Triple Helix' theoretical framework (Etzkowitz et al., 2000), which brings together universities, governments and industry, and highlights the increasing role that universities play in innovation across sectors and the wider economy as a whole (Etzkowitz and Leydesdorff, 1999; Gibb et al., 2009). Within this, the 'Entrepreneurial University' concept can be seen as one focal point (Gibb et al., 2009), university development of close ties developed through on-going mutually beneficial knowledge exchange underpinning the model (Etzkowitz and Leydesdorff, 2000, Etzkowitz, 2003), that can be seen as entrepreneurial in nature. TSA activities develop university linkages with business strengthening the Triple Helix (Gibb et al., 2009).

Wright et al., (2004) suggest a range of formal and informal TSA mechanisms through which knowledge creation and dissemination can be encouraged more widely, for example, licensing and technology transfer. The university can utilise a range of structures through which to do this, including incubators, joint ventures, start-ups and spin-outs (e.g. see Berggren and Lindholm Dahlstrand, 2009).

Birley (2002), however, also highlights a number of potential university management and governance-related barriers which work against this new entrepreneurially focused university paradigm (e.g. see Bok, 2003; Etzkowitz, 2003; 
Morrison, 2004). Frenz and Oughton (2006) also discovered that the level of direct UK firm-UK university cooperation is very low, concluding more generally that firms must also have a certain level of absorptive capacity to provide legitimacy before entering into cooperation with a university. To follow, therefore, will be an overview of the various activities that make up the third stream activities (TSA) of Universities in the UK. These range from contract research and consultancy, more traditional patents to licensing, and spinoffs of various types.

\section{Contract Research, Consultancy Contracts and Facilities}

In addition to short term monetary gain for the university, contract research can also enhance relationships with industry (Prince, 2007; Woolgar, 2007), assist spin-off creation (Van Looy et al., 2011), complement other knowledge exchange activities (Landry et al., 2010; Van Looy et al., 2011) and benefit the local region more than (inter)nationally (Schartinger et al., 2002). Powell (2012) also suggests that universities engaging with SMEs can help drive innovation and help them create sustainable growth. Universities can also provide facilities and equipment for businesses for a fee, in turn receiving payment, encouraging entrepreneurial behaviour with the facilities whilst also generating an income (Etzkowitz, 2003; Mian, 1996).

Indeed, Huffman and Quigley (2002) suggest one of the reasons for the success of Silicon Valley was because firms could access the facilities and equipment of Stanford University, as well as Stanford creating an industrial park on university owned land to facilitate business co-location and enhance knowledge sharing and diffusion. Unsurprisingly, therefore, many universities now have science parks and new firm incubators for these very reasons.

\section{Patenting and Licensing}

The addition of a third stream mission often simply exploits universities' core existing TSA strengths given that Universities have been centres for knowledge creation for centuries and dedication to research is often cited within universities' vision and mission declarations [Cambridge 2012; Cardiff 2012]. Patenting also, however, also forms an important component of the entrepreneurial university, protecting its intellectual property (Baldini, 2009; Crespi et al., 2011).

The traditional importance of patenting to firms' (and universities') innovation, economic growth and productivity means that, unsurprisingly, there has been plenty of academic attention (Baldini, 2009; Crespi et al., 2011), though there has been a downward trend in this activity since the turn of the 21st century (Leydesdorff and Meyer, 2010). One-way universities can then exploit their patent is through the sale of licenses to firms, providing the university with a royalty income substantial in some cases, for example Gatorade (Gatorade, 2012).

Licensing is therefore inherently linked to the number of disclosures and patents generated by a university as a license is exploiting the patent. Siegel et al., (2008) show a positive and significant increase in licensing numbers from increased disclosures by a university. Unsurprisingly, therefore, many studies have used licensing (or licensing income) as one of the measures of a university's' knowledge transfer or economic success (Caldera and Debande 2010; Conti and Gaule 2011; Siegel et al., 2008; Thursby et al., 2007). Siegel et al., (2008), however, also suggest that different types of Universities require different approaches in their exploitation of knowledge, with larger, older Universities often less focused on licensing, preferring alternative methods of knowledge transfer. 
Spin-offs and Start-ups

Another, related, method for exploiting university research is the creation of spin-offs, there being various types of spin-off categorisations within this field used by the HEBCIS within this study. Universities have been directly creating spin-off companies for decades and such university spin off activity is increasing (PACEC, 2009). (Shane, 2004), benefitting the university and the economy (Shane, 2004).

Hannon et al., (2005) also, however, identified the key role of the HE sector in the process of increasing the levels of graduate entrepreneurship given that although self-employment is chosen by a minority of graduates, it is also a key source of entrepreneurial activity in the UK (Prospects Net, 2007). Holden et al., (2007) therefore identify the need for ongoing, more sophisticated, research in the graduate entrepreneur area.

In terms of spin off research, however, most studies have only explored whether a university is creating a spin-off, not differentiating between different types of spinoff (which are included in the HE-BCIS survey). Whilst some have differentiated between sponsored and unsponsored spin offs (Bathelt et al., 2010), or orthodox, hybrid or technological (Nicolaou and Birley, 2003), there is a lack of use of the categorisations used in the HE-BCIS to analyse UK universities. Specifically noteworthy in this regard is the study by Åstebro et al., (2012) which uses graduate and staff spin-offs (start-ups). They note, however, the lack of studies including the creation of graduate start-ups when assessing universities TSA. It is this specific context, therefore that this study discusses graduate entrepreneurship, rather than in terms of the broader impact of university entrepreneurship education, discussed in more detail elsewhere (Kassean et al, 2015; Pittaway and Cope, 2007) or the graduate as entrepreneur (e.g. see Pickernell et al, 2011).

This review of the literature therefore identified a number of potential variables which are of potential use in the analysis. These include; contract research and consultancy contracts, as here the university is engaging with businesses to diffuse knowledge whilst also receiving third stream revenue (Perkmann et al., 2011; Van Looy et al., 2011). Universities can also provide facilities and equipment for businesses for a fee, inclusion of this as a variable appearing to be unique within the context of entrepreneurial universities.

Patenting also forms an important component of the entrepreneurial university as this is where a university is protecting its intellectual property (Baldini, 2009; Crespi et al., 2011). Licensing has also been used to analyse the entrepreneurial university and so it seems prudent to include this in analysis of entrepreneurial universities (Caldera and Debande, 2010; Powers and McDougall, 2005).

Another of the ways that universities exploit their research is spin-off creation. In creating a spin off, the university is looking to exploit their research for their own commercial gain (Shane, 2004). The addition of other forms of start-up, such as graduate start-ups in the entrepreneurial university paradigm is newer but seems sensible as universities are increasingly encouraged, more broadly to create entrepreneurs through entrepreneurship education activities. Given the study by Pickernell et al, (2011), that showed that graduate entrepreneurs (i.e. SME owners with a university degree) have "significant direct and indirect benefits that are of use to further entrepreneurial activity", this alsosuggests that the development of graduate entrepreneurs through university start-up could also play a key role in the future economic development of local, regional and national economies. 


\section{Method}

The data source used for the analysis within this paper, is the UK's Higher Education Business and Community Interaction Survey (HE-BCIS). The HE-BCIS is carried out annually by the Higher Education Statistics Agency (HESA) and is a comprehensive collection of data regarding the financial activities of universities in the UK.

Whilst there have been reports of Universities providing unreliable information (Rae et al., 2010), which could lead to inaccurate results, the HE-BCIS as a Government sponsored collection of data, can be considered the most comprehensive dataset available to researchers and so universities should be accurately reporting their activities. Rosli and Rossi (2014) also note that it is broad in scope and that other countries are seeking to adopt similar survey methods so that they can have a greater indication of the third stream activities of their universities.

The 2009/10 survey included data from all 168 of the UK's Higher Education Institutions (HEIs) and forms the basis of the analysis within this paper. Information was collected from all of the possible types of commercial activities that universities in the UK were engaging in.

The HE-BCIS contains wide ranging information regarding the commercial activities of universities within the UK. These include; disclosures, patenting, licensing, spin-offs generated, contract and consultancy research, provision of Continuing Professional Development, provision of Continuing Education and allowing the use of facilities and equipment.

Many of these different avenues for commercial activities are then disaggregated to include data related to the type of organisation with which the university is engaging with. For instance, licensing is broken down into six specific categories; software SME, software non-SME, software non-commercial, non-software SME, non-software non-SME and non-software non-commercial.

For spin-offs there are four different types identified based upon the ownership of the new venture; HEl Owned, non-HEI Owned, Staff Owned and Graduate Owned. This additional data, compared to other studies (Avnimelech and Feldman, 2011; Caldera and Debande, 2010), provides researchers with the ability to delve deeper into the specifics of the commercial activities of Universities in the UK.

Due to the heterogeneity of the $\mathrm{HE}$ sector within the UK and the inclusive nature of the HE-BCIS, however, there was a need to identify universities that were not actively engaged with, or did not submit data for, their commercial activities. Analysis of the data for 2009/10 identified 24 universities with insufficient data to include within this study. Their removal from the data used for future analysis reduced the size of the dataset but also made the analysis more robust for use with statistical software.

Previous studies have typically chosen a small number of the commercial activities of universities to study in terms of entrepreneurship, based upon logic. Åstebro et al., (2012) and Di Gregorio and Shane (2003) used start-ups, Siegel et al., (2003) used licensing whilst Avnimelech and Feldman (2011) and Caldera and Debande (2010) used a combination of commercial activities. Åstebro et al., (2012) suggest in addition to the regular commercial activities of universities, the university's ability to develop graduate start-ups should be studied as this is currently under researched within the literature. 


\section{Statistical Analysis Methods}

Because this study aims to identify whether there are groups of university activities that can be seen as entrepreneurial, being engaged in by universities in the UK, rather than individual activities, Principal Component Analysis (PCA) was identified as the most relevant method for this analysis. PCA allows a researcher to reduce the size of a dataset whilst keeping as much of the information as possible (Field, 2009). PCA produces a number of "factors" which include a number of correlated variables and accounts for a large proportion of the variance within that group of variables (Field, 2009).

Entering a whole range of variables relating to the external interactions of universities and then allowing statistical analysis to confirm which variables to subject to further analysis has not been used in this way before. This method of dependent variable generation provides a unique insight into the statistical similarities between various variables relating to entrepreneurship; knowledge creation, exchange and exploitation).

There is a lot of debate amongst PCA theorists over the correct way to retain factors, the most basic is to keep those with an eigenvalue above 1. Costello and Osborne (2005), however, recommend a scree plot be used to visually observe the point that eigenvalues naturally flatten. This method was used to identify those factors which were to be retained.

There were 144 universities included within the PCA. As stated previously, 24 of the 168 available universities were removed due to them not being engaged in the majority of the activities that we were analysing. There were 35 variables initially included within the PCA, with 16 variables remaining at the end (See Table. I). The 19 variables removed from the PCA were for two main reasons; a value of less than 0.5 in the rotated factor loadings or cross loadings of greater than 0.2 difference.

\section{Table I}

\section{Table I to be inserted here}

As you can see from Table I, there are a wide range of variables that are related to the third stream activities of universities in the UK. The broad categories into which these variables can be seen to reside have been studied in the past when considering the activities of Universities. This ensures that we are grounded within theory; these activities have already been shown in the literature to be important to Universities' commercial success.

The PCA allows us to see how these activities fit together statistically, into distinct groups.

\section{Variables Removed During the Principle Component Analysis}

In terms of the variables omitted, some of which are obviously important in the literature, this was for reasons of crossloading of the variables onto multiple factors. The variables omitted included those concerning consultancy contracts (which make up the second largest revenue stream for Universities (HE-BCIS 2010)), all of the different types of licensing (software/non software and by the type of business), as well as firm use of university laboratories or digital media suites (HE-BCIS 2010).

There could be many reasons for the removal of the variables in the PCA, for instance, the number of licenses had a high crossloading across two of the groups 
identified. The high crossloading suggests that they are accounted for by the UKEA variable, albeit implicitly due to their similarity (high value and crossloaded). For similar reasons as consultancy, some of the patenting variables and those related to facilities and equipment were also removed from the PCA.

\section{Results}

\section{Different Groups of University Commercial Activities}

The PCA produced four distinct factors (or groups of statistically related variables). Specifically, the PCA produced three factors related to spin-offs, labelled as "Staff Spin-off Activity", "Non-HEI Owned Spin-Off Activity" and "Graduate Start-up Activity". The other factor has been named "University Knowledge Exploitation Activity (UKEA)" and this factor encompasses a wide range of knowledge creation, exchange and exploitation activities, the details shown in Table II below. These factors created by the PCA cover a wide range of variables that have been previously studied in the context of entrepreneurial universities. Here we can see how these individual variables are related to each other (within each of the factors) whilst being fundamentally different to the other factors (i.e. between factors). We can see, for example, that contract research with various actors, disclosure of patents, patent applications, patents granted and university owned spin-offs appear to have similar constructs. This suggests that a university engaging in high levels of contract research will be generating patents and forming university owned spin-offs to exploit their research.

The PCA also created 3 separate factors relating to various types of spin-offs, suggesting that these activities are fundamentally different both from each other and the UKEA factor. This might suggest different institutional factors at play (such as research funding, teaching focus or research quality for example) driving each of the different factors identified by the PCA which is an interesting area for future research.

\section{Table II}

\section{Table /l to be inserted here}

\section{Note [1]: additional checks for statistical robustness}

Factor 1: University Knowledge Exploitation Activity encompasses a wide range of what can be seen as "traditional university knowledge creation, exchange and exploitation activities" most closely associated with entrepreneurial universities, and explains almost half the total variance explained by the factors. Factor 2: Staff Spin-off Activity includes staff spin-off activity, creating companies set-up by current (or recent) HEl staff but not based on IP owned by the university (HESA, 2012), and explains around a fifth of the total variance explained by the factors. Factor 3: NonHEI Owned Spin-Off Activity is defined by HESA (2012) as including companies based on IP that has originated from within the HEI but where the HEI has released ownership through sale of shares and/or IP etc. This factor explains just over one sixth of the total variance explained by the factors. Finally, Factor 4: Graduate Startup Activity is defined as including new business started by recent (within two years) graduates regardless of where IP resides, and where there has been formal business/enterprise support from the $\mathrm{HEI}$, making this factor most closely related to 
enterprise education type activities. This explains around an eighth of the total variance explained by the factors.

\section{University Knowledge Exploitation Activity}

The UKEA factor consists of nine variables and can be seen to encompass the variables most directly associated with entrepreneurial universities. These include; different types of contract research, number of disclosures, new patent applications and new patents granted, number of active HEl owned spin-offs, number of HEI owned spin-offs survived for three years and the estimated employment of HEI owned spin-offs (See Table III for an overview of the component variables within the dataset).

As previously stated, many studies have attempted to use some of these variables individually as their dependent variable to be studied (Åstebro et al., 2012; Azagra-Caro, 2007; Caldera and Debande, 2010; D’Este and Perkmann, 2011; Freitas et al., 2013; Powers and McDougall, 2005; Van Looy et al., 2011). Using PCA, however, it can be shown that, statistically, processes such as patenting and spinning-out of university know-how are correlated, whilst the Cronbach's Alpha score suggests that each of the component variables are, in essence, measuring the same thing (IBM, 2014).

In addition, also related are contract research with SMEs, non-SMEs and noncommercial organisations. Abreu et al., (2009) studied the external interaction activities of academics and found that the majority of academics' time working with industry was through joint research, contract research and consultancy services. The HESA (2012) definition of contract research states that it: "Must be identifiable as the institution meeting the specific research needs of external partners" and does not include basic research grants. The HE-BCIS also shows that contract research is the largest source of third stream income for universities in the UK (HE-BCIS, 2010). The 144 institutions in this analysis took part in 28,591 research contracts, The total value of contract research to the 144 UK universities was £983.5 million, with most of this money focused on the top research universities with Oxford University generating the most at just over £95 million. This confirms the importance of the inclusion of these variables within the PCA when we consider traditional entrepreneurial activities of universities and is consistent with the existing literature.

\section{Table III}

\section{Table III to be inserted here}

The PCA in this study also identified three different variables relating to $\mathrm{HEI}$ owned spin-offs being merged together. These are the number of active HEl owned spin-offs, the number of HEl owned spin-offs survived three years and the estimated employment of the HEl owned spin-offs. The PCA provided here provides some contradiction to the work of Rothaermel and Thursby (2005) with firms active, firms survived three years and employment being statistically, the same thing with regards to variance and so measuring them separately is not necessary.

Relying purely on the number of currently active spin-offs, according to previous studies, does not provide sufficient information on the success of spin-off as many do not survive for long (Rothaermel and Thursby, 2005). Rothaermel and Thursby (2005) found that over the six year period of their study there was a $52 \%$ failure rate amongst firms within the incubator. 
The inclusion of estimated employment is also of interest when considering what universities are being encouraged to do by policymakers, namely to drive employment of benefit to the university and the economy. This is an important component of the often-cited Triple Helix (Gibb et al., 2009).

The inclusion of the three $\mathrm{HEl}$ owned spin-off-related variables completes the composition of the first factor generated in the PCA. These nine variables are closely related to each other and in essence, the PCA has identified these activities as measuring the same thing, which can be seen as entrepreneurial TSA activity which primarily benefits the university itself. Unsurprisingly, therefore these nine variables make up the group of university entrepreneurial activity that explains the greatest degree of overall variance.

Now that we have discussed the variables that formed (or did not form) the UKEA group of entrepreneurial activities it is time to discuss the other three groups of entrepreneurial activities and their component variables.

\section{Staff, Non HEl-Owned and Graduate Spin-off and Start-up Activity}

Using PCA it was found that spinning off companies was an essential component of a university's' entrepreneurial activities and that there are fundamentally four different types of spin-offs that can be created at a university. Previous studies have shown that university spin-offs are an important component of Entrepreneurial Universities (Åstebro et al., 2012; Gibb et al., 2009; Siegel et al., 2008). Spin-offs have also been used as the dependent variable in many studies; Savage (2006) studied spin-offs from Oxford University, Gilsing et al (2011) studied the impact of regional policy on spin-offs, Link and Scott (2005), Powers and McDougall (2005), Siegel et al., (2008) and Van Looy et al., (2011) all looked in to the determinants of spin-off formation.

There appears to be a gap in the literature, however, regarding the different types of spin-offs that can be created from within a university. Within UKEA we discussed HEl Owned Spin-offs but the PCA also showed that non-HEl owned, staff and graduate spin-offs (start-ups) are also important, generating separate factors.

By definition a staff spin-off is set up by a current (or recent) member of staff where the university has no claim to the IP. These types of spin-offs are the least common type being produced by Universities in the UK. The HE-BCIS (2010) shows that there were 286 active staff spin-offs in the sample with 183 having survived for three years or more. HESA (2012) define this type of spin-off as: "Companies set-up based on IP that has originated from within the HEI but which the HEI has released ownership (usually through the sale of shares and/or IP)". There were also 1053 active spin-offs classified as non-HEI owned within the HE-BCIS (2011) with 140 of those having survived for three or more years. Finally, according to the HE-BCIS (2010) there were 2114 graduate spin-offs created during the 09/10 year with 1999 graduate start-ups having survived three years.

This gives a total of 2,322 spin-offs that have survived for three years from the 144 Universities within this study (see Table III). The turnover from the active spinoffs (non-HEl owned/staff/graduate) comes in at approximately $£ 1.3$ billion and shows the importance of spin-offs to the British economy (HE-BCIS, 2010).

\section{Table IV}

Table IV to be inserted here 
Lockett and Wright (2005) used the number of spin-offs created and the number of equity investments received to assess the impact of university resources and capabilities. Wright et al also performed a similar study that included the amount of investment that university spin-offs were generating (Wright et al., 2006). Previous studies in to spin-offs have often focused on trying to provide a typology to classify the types of spin-offs (Mustar et al., 2006). Broadly, the typologies used have come down to three perspective categories; the institutional link, the business model or the resources (Mustar et al., 2006).

There appear to be no previous studies, however, that have made use of the fact that there are different types of spin-offs from within universities in the UK as identified by the HE-BCIS. Astebro et al., (2012) used the closest classifications for spin-offs to those used identified by PCA in this study. However, they only used faculty and graduate start-ups rather than the four different types included here (Åstebro et al., 2012).

Previous studies such as those by D'Este and Perkmann (2011) or Powers and McDougall (2005) used university spin-offs as their dependent variable. The PCA produced during this study suggests both that actually there are four different types of university spin-off that are inherently different from one another, and that university owned spin offs are part of a broader factor.

Graduate start-ups, have not been widely studied within the literature, Åstebro et al., (2012) noting this to be the case and analysing data from the USA and Sweden on graduate start-ups. Åstebro et al., (2012) found the number of new graduate start-ups far outweighs the number of staff spin-offs, mirroring the HE-BCIS data for the UK.

A study of US based academic institutions by Avnimelech and Feldman (2011) used staff spin-offs as their dependent variable, but it appears that they used "academic staff spin-offs" as an all-encompassing term that includes all of the spinoffs generated within the university. This differs from the PCA approach used in this study as it differentiates between the types of spin-offs by their ownership, important because, as Avnimelech and Feldman (2011) found, there is a need for institutions to understand the trade-off between activities that lead to licensing and creating spinoffs, requiring careful deliberation when choosing the best method of exploiting their IP. This might also explain why licensing needed to be excluded from the PCA. However, this is a possible explanation and would require further investigation to understand the relationship properly.

Harrison and Leitch (2010) also argue that spin-offs from UK universities typically remain small and those academics that spin-off a company are less likely to want to drive growth of the new business than a "classic entrepreneur" would. Conversely, graduates are far more likely to want to grow their new business because it is often their sole job, academics having a balancing act between being an academic and being an entrepreneur (Harrison and Leitch, 2010; Jain et al., 2009; Lacetera, 2009). This also lends weight to the worth of the PCA approach, which has produced factors that identify the different types of spin-offs being developed at Universities.

\section{Discussion}

Ranking the Top 10 Universities in Each Group of Entrepreneurial Activities Using a simple ranking of the universities for each separate group of entrepreneurial activities shows some interesting illustrations with regards to the ranking of universities by their engagement in the different sets of activities. In addition, we 
can tentatively suggest that certain types of university are better at generating entrepreneurial outcomes through UKEA, others are better at developing graduate entrepreneurs, the other types of activities showing mixtures of types.

\section{Table V}

Table $V$ to be inserted here

In terms of the highest rankings for the individual sets of activities in each category, for UKEA, Table $V$ shows that, unsurprisingly, all of the top 10 universities belong to the Russell Group of universities. The very nature of the components of the UKEA factor suggest that this type of activity will likely be driven by research funding and research quality, dominated by the most research active and best funded universities.

In contrast to those universities achieving high rankings using UKEA, are those creating the most staff spin-offs (See Table VI). We can see that there are fewer Russell Group universities and a likely greater variation amongst the universities with regards to their research quality, funding and focus (teaching or research). Indeed, only Southampton, Cambridge and Edinburgh Universities are in the top ten for both UKEA and staff spin-offs.

\section{Table VI}

Table VI to be inserted here

Non-HEl Owned Spin-offs also show different universities being in the top ten as shown in Table VII . Again, we see that a number of Russell Group universities are in this top ten, with Edinburgh and Cambridge Universities also being in the top ten for staff spin-offs.

\section{Table VII}

Table VII to be inserted here

Finally, when we consider the top ten universities for graduate start-ups we can see in Table VIII a real difference with the three previous top ten rankings. Russell Group universities are far less common, with three of the top ten being universities dedicated to the Arts. It appears, therefore, that the newer universities are more capable of producing graduate entrepreneurs than most of the older more research intensive universities.

\section{Table VIII}

Table VIII to be inserted here

As we can see from these examples, there are a number of universities that are very good at more than one type of entrepreneurial activity (Cambridge 
appearing in the top ten for three of the factors). Conversely, some universities are very good at driving graduate start-ups but seem generally engage less in the other groups of activity.

We can see from the 4 tables above that there is a great variation between the universities coming in the top 10 across the 4 factors used in the analysis. What this means for the debate around the entrepreneurial university is of interest to many stakeholders. Specifically, the results here suggest that the exploitation of university held (owned) knowledge, through patents, contract research and university owned spin-offs is just one part of a wider set of entrepreneurial activities that universities undertake idea. Given the diversity in terms of the universities in the top 10s for each of the different factors it appears, although more research is needed, that staff owned spin-offs, non-HEl owned spin-offs and especially graduate start-ups are driven by something other than the research standing of the individual university (at least as indicated by Russel group membership). Identifying what is causing this result could therefore enable stakeholders (including government policymakers) to better encourage the different avenues of entrepreneurship

\section{Conclusions}

Through the analysis of the literature surrounding the entrepreneurial activities of universities, it became apparent that there was a theme emerging. Previous studies focused upon a few specific measures of a university's' external interactions such as; patenting, licensing, spin-off creation, consulting or contract research. Typically researchers would choose one (or several) of these activities and then analyse the impact of a range of independent variables.

Through the analysis of the literature it became clear, however, that whilst the "Entrepreneurial University" has been widely discussed and theories put forward for the activities that they engage in, there have been few studies to mathematically identify those groups of activities. Instead, the choice of dependent variables (whether that be patenting or licensing) has always been down to the researcher's choice. This study, through the use of PCA, has mathematically identified the dependent variables of relevance to future research.

The fact that three different types of contract research, along with university owned spin-off activities and generating and patenting ideas factor together is of interest to both this study and to future studies. Previous research focused on individual outputs to measure a university's' performance. This factor encompasses a range of traditional entrepreneurial activities that universities are encouraged to take part in.

PCA is underused within the relevant literature. D'Este and Perkmann (2011) used factor analysis (which is similar to PCA) but their point of study was the academic and it was used to try and find underlying motivations for engaging with industry rather than being used to generate the dependent variables. Hewitt-Dundas (2012) also used factor analysis but it was used more narrowly to identify different types of university based upon their RAE score.

Many previous studies have also been more selective in terms of their sample. Siegel et al., (2008) used 37 Universities from the UK (from the top 98 with the highest research income) and 83 Universities from the USA. This small and selective sample doesn't represent the heterogeneous nature of the UK higher education sector. By way of contrast, the PCA in this study includes 144 of the 168 
HEls in the UK, allowing this study a greater degree of generalisability to the UK sector as a whole.

This novel approach in this area of research has allowed the researcher to identify four unique groups of entrepreneurial activities that universities are engaging in. "University Knowledge Exploitation Activities" (UKEA) is the most wide-ranging and, importantly, includes many activities analysed in previous studies as separate activities (see Caldera and Debande, 2010; D'Este and Perkmann, 2011; Link et al., 2005; Siegel et al., 2008; Van Looy et al., 2011). This suggests that all these activities are in some-way related, the power of the result coming from the fact that statistically these variables can be grouped together into a single factor when considering the $144 \mathrm{HEls}$ across the UK included in this study.

The contribution to knowledge from this variable, therefore comes from the way that it was generated (through PCA) and because of the way that these different types of activities (patenting, contract research and spin-offs) come together statistically. These activities cover a wide range of the entrepreneurial activities of universities from knowledge creation and exchange to exploitation. The general nature of this factor is also of real interest to policy makers in trying to understand what groups of entrepreneurial activities at universities are similar. Interestingly, licensing and consultancy contracts did not form any part of these groups of entrepreneurial activities which were identified during the PCA even though the 4 groups of activities accounted for $77 \%$ of the variance in the data.

The other three groups of activities identified by the PCA relate to different types of spin-offs and start-ups created at the university with ownership of the spinoffs being the differentiator. "Non-HEl Owned Spin-offs", Staff Owned Spin-offs" and "Graduate Start-Ups" were all identified. The use of graduate start-ups when analysing entrepreneurial universities has been largely understudied and so this provides an important contribution to the knowledge surrounding entrepreneurial universities, particularly given the lack of overlap between universities showing strong results for both UKEA and graduate entrepreneurship (Oxford being a notable exception).

This has interesting potential implications for government policy as well as proving interesting for university stakeholders and policy makers because the UK Government has traditionally focused research funds on a select number of universities, typically those who are part of the Russell Group (DES, 2003). In 2010/11, the Russell Group of 24 universities received $72 \%$ (over $£ 3.2$ billion) of UK universities' research grant and contract income and 74\% (over $£ 1.1$ billion) of total income from the Research Council (Russell Group, 2012).

The reasons for this concentration of research funds are numerous, but the most common stated reason is that a concentration of funds allows universities to focus upon research and so attract the best talent and conduct the best research (DES, 2003). What this means for commercial activities such as patenting or spin-off creation that rely on the creation of commercial knowledge or technologies is that universities with the most research funding are most able to conduct these types of commercial activities.

This concentration of funds within the UK can also, however, cause a reinforcing feedback loop because of the way the allocation of research funds works. Enhanced research funding means that a university is able to carry out more research and of a higher standard. This in turn allowed them to submit more research to the Research Assessment Exercise (RAE) (now the Research Excellence Framework (REF)) and so gain more funds thereby completing the funding loop. This may, however, be 
detrimental to universities outside the Russell Group, potentially affecting their ability to engage in high levels of other types of TSA, specifically related to the spin out and start up activity identified in this study. There is also a worry that universities could be further encouraged to focus on their own revenue, leading to ever more applied research (which is more suitable for commercialisation) at the expense of basic research and the original university mission of helping society. The inclusion of a wider range of activities than have traditionally been included when discussing the "entrepreneurial university" as identified by work such as Etzkowitz (2003) also highlights the potential relevance of an alternative approach, nearer to Woollard's (2007) more widely defined "enterprising university", which can be seen include other activities such as the non-university owned spin offs and graduate start ups identified in this study (as well as the undiscussed entrepreneurship education). ). This also suggest that the "Knowledge Spillover Theory of Entrepreneurship" (Acs et al., 2009) is also relevant here, as this highlights that knowledge (for example created by universities) can spill over indirectly into the economy to be exploited by (non-university owned spin out) entrepreneurs (rather than the university itself).

In order to more fully inform government policy and university practice, however, there are a number of limitations to this research, however, which imply a need for further research in this area. For example, whilst the methodology was novel and exploratory, it was limited to the UK context, and used a single year of data. There are therefore obvious limits to the generalisability of these findings to the international HE sector. Whilst steps were taken to ensure that those variables identified in the literature were included to help keep us grounded in existing theory, the nature of this study means that it has also generated a number of interesting new research areas because of the factors generated. These factors clearly require further study in terms of how they themselves are driven by institutional factors. Study of the drivers of different types of entrepreneurial university behaviour identified here is beyond the scope of this study, however, and therefore constitutes another limitation to this research.

In terms of further research, therefore, expanding the dataset to a more international scope would, help with the generalisability of these findings, as would a study using a number of years of UK data. Further study into what is driving these various groups of entrepreneurial activities is also needed to begin to understand how variables such as research funding, research quality and / or whether a university is teaching focussed influences the entrepreneurial activities being engaged in. Understanding how research funding and research quality influence entrepreneurship through different channels is thus an important policy-related question for the future as we have shown that there are various channels for entrepreneurship and universities seem to exploit each channel to varying degrees. This will therefore build on the research undertaken here to gain a better understanding of whether government and university policy should focus upon research quality-based measures of the "impact" that universities are having or whether universities can have greater impact in different ways, such as through the creation of graduate entrepreneurs.

\section{Note}

1. Kaiser-Meyer-Olkin Measure of Sampling Adequacy $=0.818$ indicating sampling adequacy (Field, 2009; Kaiser, 1970). Principle Components were 
kept in accordance with recommended eigenvalues of at least 1 as recommended by Costello and Osborne (2005), a scree plot was used to confirm this visually. Components were removed from the principle component analysis if they did not have a rotated factor loading of above 0.5 and cross loadings of greater than 0.2 difference were removed (Field, 2009).

\section{References}

Abreu, M., Grinevich, V., Hughes, A. and Kitson, M. (2009), "Knowledge exchange between academics and the business, public and third sectors", available at: http://www.jbs.cam.ac.uk/fileadmin/user upload/centre-for-businessresearch/downloads/special-reports/specialreportknowledgeexchangeacademics.pdf (accessed 21 October 2010).

Acosta, M., Coronado, D. and Martinez, M.A. (2012), "Spatial differences in the quality of University patenting: Do regions matter?", Research Policy, Vol. 21 No.4, pp. 693-703.

Acs, Z., Braunerhjelm, P., Audretsch, D. and B. Carlsson, (2009). "The knowledge spillover theory of entrepreneurship" Small Business Economics, Vol 32 No 1, pp.1530.Åstebro, T., Bazzazian, N. and Braguinsky, S. (2012), "Startups by recent University graduates and their faculty: Implications for University entrepreneurship policy”, Research Policy, Vol. 41 No. 4, pp. 663-677.

Avnimelech, G. and Feldman, M. (2011), "The impact of institutional quality, cluster strength and TLO licensing capacity on the rate of academic staff spin-offs", paper presented at Atlanta Conference on Science and Innovation Policy, October 2011, available at: https://smartech.gatech.edu/bitstream/handle/1853/42585/622-1756-1PB.pdf?sequence $=1$ (accessed 7 January 2013)

Azagra-Caro, J.M. (2007), "What type of faculty member interacts with what type of firm? Some reasons for the delocalisation of University-industry interaction", Technovation, Vol. 27 No. 11, pp. 704-715

Baldini, N. (2009), "Implementing Bayh-Dole-like laws: Faculty problems and their impact on University patenting activity", Research Policy, Vol. 38 No.8, pp. 12171224

Bathelt, H., Kogler, D.F. and Munro, A.K. (2010), "A knowledge-based typology of university spin-offs in the context of regional economic development", Technovation, Vol. 30 No. 9-10, pp. 519-532

Behrens, T.R. and Gray, D.O. (2001), "Unintended consequences of cooperative research: impact of industry sponsorship on climate for academic freedom and other graduate student outcome", Research policy, Vol. 30 No.2, pp. 179-199.

Benneworth, P., (2007), "Seven samurai opening up the ivory tower? The construction of Newcastle as an entrepreneurial university", European Planning Studies, Vol. 15 No.4, pp. 487-509 
Bercovitz, J. and Feldman, M. (2006), "Entrepreneurial universities and technology transfer: A conceptual framework for understanding knowledge-based economic development", The Journal of Technology Transfer, Vol. 31 No.1, pp. 175-188.

Berggren, E. and Lindholm Dahlstrand, Å. (2009), "Creating an entrepreneurial region: Two waves of academic spin-offs from Halmstad University", European Planning Studies, Vol. 17 No.8, pp. 1171-1189.

Birley, S. (2002), "Universities, academics, And spinout companies: lessons from Imperial", International Journal of Entrepreneurship Education, Vol.1 No.1: pp. 1-21.

Bok, D. (2003), Universities In The Marketplace: The Commercialisation Of Higher Education, Princeton University Press, New Jersey.

Caldera, A. and Debande, O. (2010), "Performance of Spanish Universities in technology transfer: An empirical analysis", Research Policy, Vol. 39 No.9, pp. 11601173.

Cambridge. (2012), Cambridge University mission statement, available at: http://www.cam.ac.uk/univ/mission.html (accessed 4 May 2012)

Cardiff. (2012), Cardiff University mission and vision statement, available at: http://cardiff.ac.uk/about/visionandmission/index.html [accessed 4 May 2012]

Conti, A. and Gaule, P. (2011), "Is the US outperforming Europe in university technology licensing? A new perspective on the European Paradox", Research Policy, Vol. 40 No. 1, pp. 123-135.

Costello, A.B. and Osborne, J.W. (2005), "Best practices in exploratory factor analysis: Four recommendations for getting the most from your analysis", Practical Assessment, Research \& Evaluation, Vol. 10 No.7, pp. 1-9.

Crespi, G., D'Este, P., Fontana, R. and Geuna, A. (2011), "The impact of academic patenting on University research and its transfer", Research Policy, Vol. 40 No.1, pp. 55-68.

Culkin, N. (2016), "Entrepreneurial universities in the region: the force awakens?", International Journal of Entrepreneurial Behaviour \& Research, Vol. 22 No.1, pp.416.

DES. (2003), "The Future of Higher Education", available at: http://www.educationengland.org.uk/documents/pdfs/2003-white-paper-higher-ed.pdf (accessed 10 January 2011).

D'Este, P. and Perkmann, M. (2011), "Why do academics engage with industry? The entrepreneurial university and individual motivations", The Journal of Technology Transfer, Vol. 36 No. 3, pp. 316-339.

Di Gregorio, D. and Shane, S. (2003), "Why do some Universities generate more start-ups than others?", Research Policy, Vol.32 No. 2, pp. 209-227.

Etzkowitz, H. (2003), "Research groups as quasi-firms: The invention of the entrepreneurial University”, Research Policy, Vol.32 No.1, pp. 109-121. 
Etzkowitz, H. and Leydesdorff, L. (1999), "The future location of research and technology transfer", Journal of Technology Transfer, Vol.24 No.2, pp. 111-123.

Etzkowitz, H., Webster, A., Gebhardt, C., and Terra, B.R.C. (2000), "The future of the university and the university of the future: evolution of ivory tower to entrepreneurial paradigm", Research policy, Vol.29 No.2, pp. 313-330.

Field, A. (2009), Discovering Statistics Using SPSS. Sage Publishing, London.

Frenz, M., and Oughton, C. (2006), "Innovation in the UK regions and devolved administrations: A review of the literature", available at:

http://webarchive.nationalarchives.gov.uk/20070603164510/http://www.dti.gov.uk/ies e/DTI regional innovation review2.doc (accessed 4 January 2011).

Freitas, I.M.B., Geuna, A. and Rossi, F., 2013. Finding the right partners: Institutional and personal modes of governance of university-industry interactions. Research Policy, 42(1), pp.50-62.

Fusion Licensing. (2012), "Licensing UK Universities' technology”, available at: http://www.fusioniplicensing.co.uk/AboutBioFusionLicensing/ (accessed 1 March 2012).

Gatorade. (2012), "Florida University and the creation of Gatorade", available at: http://www.gatorade.co.uk/heritage (accessed 8 January 2012)

Gibb, A., Haskins, G. and Robertson, I. (2009), "Leading the entrepreneurial University", available at:

http://www.ncee.org.uk/publication/leading the entrepreneurial university.pdf (accessed 6 June 2011).

Gilsing, V., Bekkers, R., Freitas, I.M.B. and van der Steen, M. (2011), "Differences in technology transfer between science-based and development-based industries:

Transfer mechanisms and barriers", Technovation, Vol.31 No.12, pp. 638-647.

Hannon, P., Collins, L. and Smith, A. (2005), "Exploring graduate entrepreneurship: a collaborative, co-learning based approach for students, entrepreneurs and educators", Industry and Higher Education, Vol. 19 No. 1, pp. 11-23.

Harrison, R.T. and Leitch, C. (2010), "Voodoo Institution or Entrepreneurial University? Spin-off Companies, the Entrepreneurial System and Regional Development in the UK", Regional Studies, Vol. 44 No.9, pp. 1241-1262.

Hatakenaka, S. (2005), "Development of third stream activity: lessons from international experience", available at: http://www.hepi.ac.uk/wp-

content/uploads/2014/02/21 Developmentofthirdstreamfunding-SachiHatakenaka.pdf (accessed 29 October 2010).

HESA. (2012), Definitions of variables. available at:

http://www.hesa.ac.uk/index.php?option=com collns\&task=show colln\&ltemid=232\& $\mathrm{c}=\mathrm{C} 10031 \& \mathrm{~s}=5 \& \mathrm{wvy}=$ any\&wvs=1\&isme $=1$ (accessed 22 February 2012). 
Hewitt-Dundas, N. (2012), "Research intensity and knowledge transfer activity in UK Universities”, Research Policy, Vol.41 No.2, pp. 262-275.

HE-BCIS. (2010), "The Higher Education Business and Community Interaction Survey", available at: http://www.hefce.ac.uk/pubs/year/2011/201125/ (accessed 10 March 2011).

Holden, R., Jameson, S. and Walmsley, A. (2007), "New graduate employment within SMEs: still in the dark?", Journal of Small Business and Enterprise Development, Vol. 14 No. 2, pp. 211-227.

Huffman, D., and J. M. Quigley. (2002), "The role of the university in attracting high tech entrepreneurship: A Silicon Valley tale", Annals of Regional Science, Vol.36, pp. 403-419.

IBM. (2014), "What is Cronbach's Alpha", available from: http://www01.ibm.com/support/knowledgecenter/SSLVMB 21.0.0/com.ibm.spss.statistics.help/i dh reli.htm (accessed 15 February 2016).

Jack, S.L. and Anderson, A.R. (1999), "Entrepreneurship education within the enterprise culture: producing reflective practitioners", International Journal of Entrepreneurial Behaviour \& Research, Vol.5 No.3, pp. 110-125.

Jain, S., George, G. and Maltarich, M. (2009), "Academics or entrepreneurs? Investigating role identity modification of university scientists involved in commercialisation activity", Research Policy, Vol.38 No.6, pp. 922-935.

Jarzabkowski, P. (2005), Strategy as practice: An activity-based approach, Sage, London.

Kaiser, H.F. (1970), “A second generation little jiffy”, Psychometrika, Vol.35 No.4, pp. 401-415.

Kassean, H., Vanevenhoven, J., Liguori, E. and Winkel, D.E., (2015).

Entrepreneurship education: a need for reflection, real-world experience and action. International Journal of Entrepreneurial Behaviour \& Research, Vol. 21 No 5, pp.690708.

Lacetera, N. (2009), “Academic entrepreneurship”, Managerial and Decision Economics, Vol.30 No. 7, pp. 443-464.

Lambert, R. (2003), "Lambert Review of Business-University Collaboration”, available at:

http://www.eua.be/eua/jsp/en/upload/lambert review final 450.1151581102387.pdf (accessed 9 November 2010).

Landry, R., Saïhi, M., Amara, N. and Ouimet, M. (2010), "Evidence on how academics manage their portfolio of knowledge transfer activities", Research Policy, Vol. 39 No. 10, pp. 1387-1403. 
Lazzeretti, L. and Tavoletti, E. (2005), "Higher education excellence and local economic development: The case of the entrepreneurial university of Twente", European Planning Studies, Vol. 13 No.32, pp. 475-493.

Lenger, A. (2008), "Regional innovation systems and the role of state: institutional design and state universities in Turkey", European Planning Studies, Vo. 16 No.8, pp. 1101-1120.

Leydesdorff, L. and Meyer, M. (2010), "The decline of University patenting and the end of the Bayh-Dole effect", Scientometrics, Vol. 83 No.2, pp. 355-362.

Link, A.N. and Scott, J.T. (2005), "Opening the ivory tower's door: An analysis of the determinants of formation of U.S. University spin-off companies", Research Policy, Vol.34 No. 7, pp. 1106-1112.

Lockett, A. and Wright, M. (2005), "Resources, capabilities, risk capital and the creation of University spin-out companies", Research Policy, Vol. 34 No.7, pp. 10431057.

Matlay, H. (2006), "Researching entrepreneurship and education: Part 2: what is entrepreneurship education and does it matter?", Education + Training, Vol. 48 No. 8-9, pp. 704-718.

McLarty, R. (2003), "Graduate Entrepreneurship: A Critical Review of Problems, Issues and Personal Competencies", International Journal of Entrepreneurship and Innovation Management, Vol. 3 No. 5-6, pp. 621-636.

Mian, S.A. (1996), "Assessing value-added contributions of university technology business incubators to tenant firms", Research Policy, Vol. 25 No.3, pp. 325-335.

Molas-Gallart, J., Salter, A., Patel, P., Scott, A. and Duran, X. (2002), "Measuring third stream activities. Final report to the Russell Group of Universities", available at: http://www.academia.edu/532097/Measuring third stream activities (accessed 22 January 2011).

Morrison, D.A. (2004), Marketing To The Campus Crowd, Dearborn Trade Publishing, Chicago.

Mustar, P., Renault, M., Colombo, M.G., Piva, E., Fontes, M., Lockett, A., Wright, M., Clarysse, B. and Moray, N. (2006), "Conceptualising the heterogeneity of researchbased spin-offs: A multi-dimensional taxonomy", Research Policy, Vol. 35 No. 2, pp. 289-308.

Nicolaou, N. and Birley, S. (2003), "Academic networks in a trichotomous categorisation of University spinouts", Journal of Business Venturing, Vol. 18 No.3, pp. 333-359.

O'Shea, R.P, Allen, T.J., Chevalier, A. and Roche, F. (2005), "Entrepreneurial orientation, technology transfer and spinoff performance of U.S. Universities", Research Policy, Vol. 34 No. 7, pp. 994-1009. 
PACEC. (2009), "Evaluation of the effectiveness and roll of HEFCE/OSI third stream funding", available at:

http://www.hefce.ac.uk/media/hefce1/pubs/hefce/2009/0915/09 15.pdf (accessed 1 January 2011).

Perkmann, M. and Walsh, K. (2008), "Engaging the scholar: Three types of academic consulting and their impact on Universities and industry", Research Policy, Vol. 37 No. 10, pp. 1884-1891.

Perkmann, M., King, Z. and Pavelin, S. (2011), "Engaging excellence? Effects of faculty quality on University engagement with industry", Research Policy, Vol. 40 No. 4, pp. 539-552.

Pickernell, D., Packham, G., Jones, P., Miller, C., Thomas, B. (2011), "Graduate entrepreneurs are different: they access more resources?", International Journal of Entrepreneurial Behaviour \& Research, Vol. 17 No.2, pp. 183-202

Pittaway, L. and Cope, J., 2007. Entrepreneurship education: a systematic review of the evidence. International small business journal, Vol 25 No 5, pp.479-510.

Powell, J. (2012), "The university role in the innovation leadership of small to medium sized enterprises. Towards "universities for a modern renaissance" (UMR)", International Journal of Entrepreneurial Behaviour \& Research, Vol. 18 No. 4, pp. 1355-2552.

Powers, J.B. and McDougall, P.P. (2005), "University start-up formation and technology licensing with firms that go public: a resource-based view of academic entrepreneurship", Journal of Business Venturing, Vol.20 No. 3, pp. 291-311.

Prince, C. (2007), "Strategies for developing third stream activity in new University business schools", Journal of European Industrial Training, Vol. 31 No.9, pp. $742-$ 757.

Prospects Net, (2007), "Graduate Entrepreneurship", available at: http://www.prospectsnet.com (accessed 19 January 2009).

Pruett, M., Shinnar, R., Toney, B., Llopus, F., Fox., J. (2009), "Explaining entrepreneurial intentions of university students: a cross-cultural study", International Journal of Entrepreneurial Behaviour \& Research, Vol. 6 No.6, pp. 571-594.

Rae, D. (2010), "Universities and enterprise education: responding to the challenges of the new era", available at:

http://eprints.lincoln.ac.uk/3680/1/JSBED.new era paper.pdf (accessed 10 September 2012).

Reddy, P. (2011), "The evolving role of universities in economic development: the case of university-industry linkages", Göransson, B, Universities in Transition, Springer, New York, pp. 25-49.

Rothaermel, F.T. and Thursby, M. (2005), "Incubator firm failure or graduation?: The role of University linkages", Research Policy, Vol. 34 No. 7, pp. 1076-1090. 
Rosli, A. and Rossi, F. (2014), "What indicators to assess universities' knowledge transfer performance? Problems in the transition from theory to practice", Hilpert, U., Handbook on Politics and Technology, Routledge, London.

Russell Group. (2012), "Russell Group of Universities research funding" available at: http://www.russellgroup.ac.uk/research (accessed 12 September 2011).

Sainsbury Review. (2007), "The Race to the Top", available at:

http://www.rsc.org/images/sainsbury review051007 tcm18-103116.pdf (accessed 2 April 2010).

Savage, B. (2006), "Spin-out fever: Spinning out a University of Oxford company and comments on the process in other Universities", Journal of Commercial Biotechnology, Vol. 12 No.3, pp. 213-219.

Schartinger, D., Rammer, C., Fischer, M.M. and Fröhlich, J. (2002), "Knowledge interactions between universities and industry in Austria: sectoral patterns and determinants", Research policy, Vol. 31 No.3, pp. 303-328.

Shane, S. (2004), Academic entrepreneurship: University spinoffs and wealth creation, Edward Elgar Publishing, Cheltenham.

Siegel, D.S., Waldman, D.A., Atwater, L.E. and Link, A.N. (2003), "Commercial knowledge transfers from universities to firms: Improving the effectiveness of university-industry collaboration", Journal of High Technology, Vol. 14 No.1, pp. 111133.

Siegel, D., Wright, M., Chapple, W. and Lockett, A. (2008), "Assessing the relative performance of University technology transfer in the US and UK: A Stochastic distance function approach", Economics of Innovation and new Technology, Vol. 17 No.7, pp. 719-731.

Smith, S., Ward, V. and House, A. (2011), "Impact' in the proposals for the UK's Research Excellence Framework: Shifting the boundaries of academic autonomy. Research Policy", Vol. 40 No.10, pp. 1369-1379.

Thursby, M., Thursby, J.G. and Gupta-Mukherjee, S. (2007), "Are there real effects of licensing on academic research? A life cycle review", Journal of Economic Behaviour \& Organisation, Vol. 63 No.4, pp. 577-598.

Van Looy, B., Landoni, P., Callaert, J., van Pottelsberghe, B., Sapsalis, E. and Debackere, K. (2011), "Entrepreneurial effectiveness of European Universities: An Empirical assessment of antecedents and trade-offs", Research Policy, Vol. 40 No.4, pp. 553-564.

Warry Report. (2006), "Increasing the economic impact of Research Councils", available at: http://www.bis.gov.uk/files/file32802.pdf (accessed 10 July 2010).

Wilson Report. (2012), "A review of business-University collaboration", available at: http://www.bis.gov.uk/assets/biscore/further-education-skills/docs/w/12-610-wilsonreview-business-university-collaboration.pdf (accessed 14 July 2012). 
Woolgar, L. (2007), "New institutional policies for University-industry links in Japan" Research Policy, Vol. 36 No. 8, pp. 1261-1274.

Woollard, D., Zhang, M. and Jones, O. (2007), "Academic enterprise and regional economic growth Towards an enterprising university", Industry and higher education, Vol. 21 No.6, pp. 387-403.

Wright, M., Birley, S. and Mosey, S. (2004), "Entrepreneurship and university technology transfer", The Journal of Technology Transfer, Vol. 29 No.3-4, pp. 235246.

Wright, M., Lockett, A., Clarysse, B. and Binks, M. (2006), "University spin-out companies and venture capital", Research Policy, Vol. 35 No. 4, pp. 481-501. 
Table I

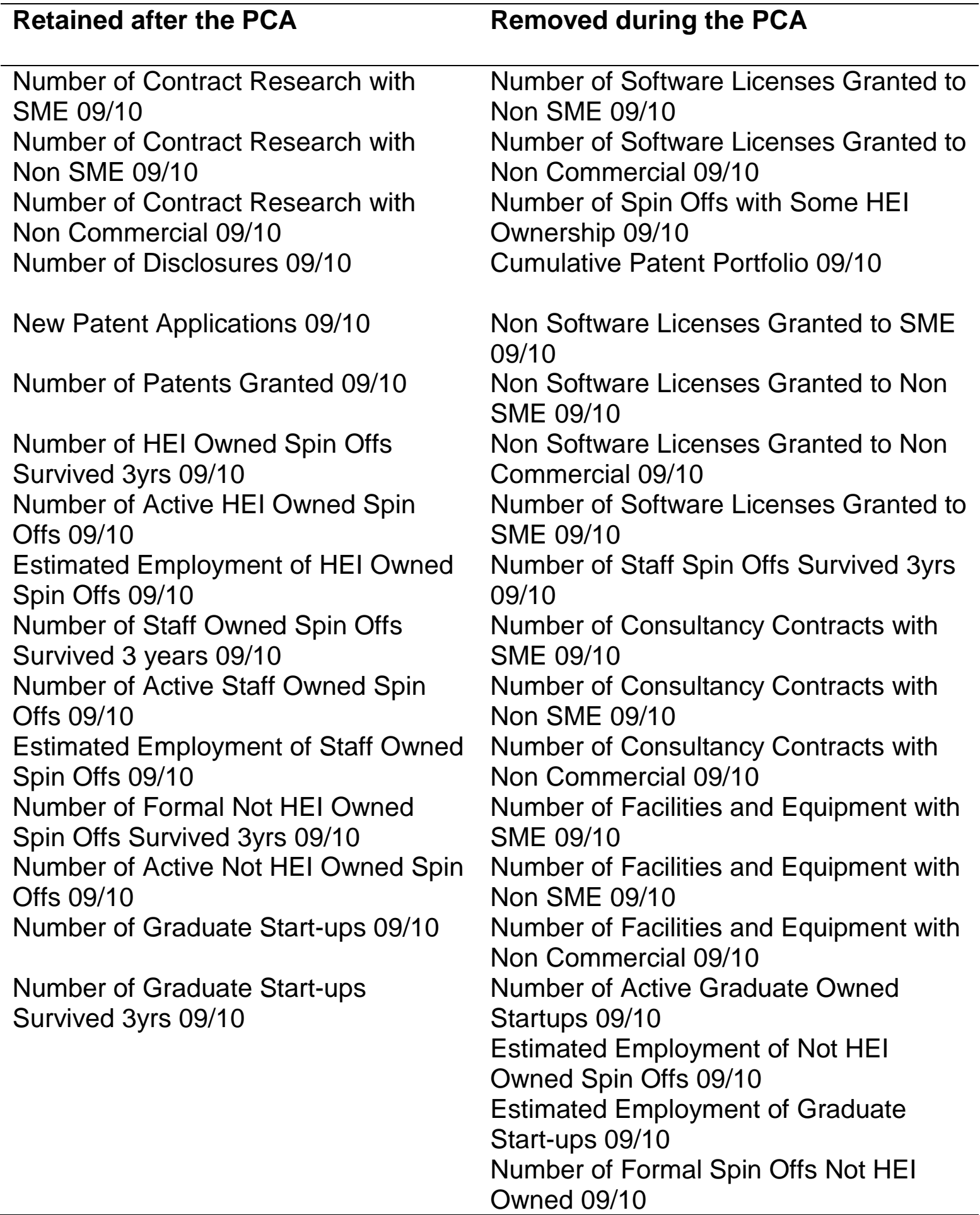




\begin{tabular}{|c|c|c|c|c|}
\hline & \multicolumn{4}{|c|}{ Component } \\
\hline & UKEA & $\begin{array}{l}\text { Staff } \\
\text { Spin- } \\
\text { offs }\end{array}$ & $\begin{array}{l}\text { non- } \\
\text { HEI } \\
\text { Spin- } \\
\text { offs }\end{array}$ & $\begin{array}{l}\text { Graduate } \\
\text { Start-ups }\end{array}$ \\
\hline Number of Contract Research with SME & 0.645 & & & \\
\hline Number of Contract Research with Non- & & & & \\
\hline SME & 0.908 & & & \\
\hline Number of Contract Research with Non- & & & & \\
\hline Commercial & 0.801 & & & \\
\hline Number of Disclosures & 0.822 & & & \\
\hline New Patent Applications & 0.755 & & & \\
\hline Number of Patents Granted & 0.758 & & & \\
\hline Number of HEI Spin-offs Survived 3yrs & 0.866 & & & \\
\hline Number of Active HEI Spin-offs & 0.835 & & & \\
\hline Estimated Employment of HEI Owned & & & & \\
\hline Spin-offs & 0.835 & & & \\
\hline Number of Staff Spin-offs Survived 3yrs & & 0.951 & & \\
\hline Number of Active Staff Spin-offs & & 0.931 & & \\
\hline $\begin{array}{l}\text { Estimated Employment of Staff Spin-offs } \\
\text { Number of Formal non-HEI Spin-offs }\end{array}$ & & 0.829 & & \\
\hline Survived 3yrs & & & 0.900 & \\
\hline Number of Active non-HEI Spin-offs & & & 0.921 & \\
\hline Number of Graduate Start-ups & & & & 0.861 \\
\hline Number of Graduate Start-ups Survived & & & & \\
\hline 3yrs & & & & 0.875 \\
\hline Eigenvalues & 5.971 & 2.623 & 2.249 & 1.551 \\
\hline$\%$ Variance Explained & 37.317 & 16.393 & 14.059 & 9.696 \\
\hline Cronbachs Alpha & 0.788 & 0.944 & 0.814 & 0.712 \\
\hline
\end{tabular}


Table III

\begin{tabular}{ll}
\hline Third Stream Activities & Instances \\
\hline Contract Research With SME & 2,507 \\
Contract Research With non-SME & 10,076 \\
Contract Research With non-Commercial & 16,458 \\
Number of Disclosures & 3,911 \\
Number of New Patent Applications & 2,012 \\
New Patents Granted & 827 \\
Active HEl-Owned Spin-offs & 789 \\
HEI-Owned Spin-offs Survived 3yrs & 1053 \\
Estimated Employment of HEl-Owned Spin-offs & 8903 \\
\hline
\end{tabular}


Table IV

\begin{tabular}{|c|c|c|c|}
\hline & $\begin{array}{l}\text { Staff Spin- } \\
\text { offs }\end{array}$ & $\begin{array}{l}\text { non-HEI Owned Spin- } \\
\text { offs }\end{array}$ & $\begin{array}{l}\text { Graduate Start- } \\
\text { ups }\end{array}$ \\
\hline Active & 286 & 1053 & 2114 \\
\hline Survived 3yrs & 183 & 140 & 1999 \\
\hline Survived:Active & $0.64: 1$ & $0.13: 1$ & $0.95: 1$ \\
\hline
\end{tabular}


Table V

\begin{tabular}{ll}
\hline University & Rank \\
\hline The University of Oxford & 1 \\
Imperial College of Science, Technology & \\
and Medicine & 2 \\
University College London & 3 \\
The University of Manchester & 4 \\
The University of Cambridge & 5 \\
The University of Edinburgh & 6 \\
The University of Birmingham & 7 \\
The University of Leeds & 8 \\
The University of Southampton & 9 \\
The University of Nottingham & 10 \\
\hline
\end{tabular}


Table VI

\begin{tabular}{ll}
\hline University & Rank \\
\hline The University of Teesside & 1 \\
The University of Southampton & 2 \\
The University of Cambridge & 3 \\
Swansea University & 4 \\
University of the West of England, Bristol & 5 \\
The University of East London & 6 \\
The University of Edinburgh & 7 \\
The University of Strathclyde & 8 \\
The University of Lancaster & 9 \\
The University of Sussex & 10 \\
\hline
\end{tabular}


Table VII

\begin{tabular}{ll}
\hline University & Rank \\
\hline The University of Edinburgh & 1 \\
The University of Cambridge & 2 \\
Ravensbourne & 3 \\
Swansea Metropolitan University & 4 \\
The University of Strathclyde & 5 \\
University of the Arts, London & 6 \\
The University of Sheffield & 7 \\
Cardiff University & 8 \\
The University of Bristol & 8 \\
The University of Newcastle-upon-Tyne & 10 \\
\hline
\end{tabular}




\section{Table VIII}

\begin{tabular}{ll}
\hline University & Rank \\
\hline The University of Central Lancashire & 1 \\
University of the Arts, London & 2 \\
University for the Creative Arts & 3 \\
Royal College of Art & 4 \\
University of Bedfordshire & 5 \\
Kingston University & 6 \\
The University of Oxford & 7 \\
Loughborough University & 8 \\
The University of Portsmouth & 9 \\
The Nottingham Trent University & 10 \\
\hline
\end{tabular}

